\title{
The Role of Apoptosis-Induced Proliferation for Regeneration and Cancer
}

\author{
Hyung Don Ryoo ${ }^{1}$ and Andreas Bergmann ${ }^{2}$ \\ ${ }^{1}$ Department of Cell Biology, New York University School of Medicine, New York, New York 10016 \\ ${ }^{2}$ Department of Cancer Biology, University of Massachusetts Medical School, Worcester, Massachusetts 01605 \\ Correspondence: abergman@mdanderson.org
}

Genes dedicated to killing cells must have evolved because of their positive effects on organismal survival. Positive functions of apoptotic genes have been well established in a large number of biological contexts, including their role in eliminating damaged and potentially cancerous cells. More recently, evidence has suggested that proapoptotic proteinsmostly caspases_can induce proliferation of neighboring surviving cells to replace dying cells. This process, that we will refer to as "apoptosis-induced proliferation," may be critical for stem cell activity and tissue regeneration. Depending on the caspases involved, at least two distinct types of apoptosis-induced proliferation can be distinguished. One of these types have been studied using a model in which cells have initiated cell death, but are prevented from executing it because of effector caspase inhibition, thereby generating "undead" cells that emit persistent mitogen signaling and overgrowth. Such conditions are likely to contribute to certain forms of cancer. In this review, we summarize the current knowledge of apoptosis-induced proliferation and discuss its relevance for tissue regeneration and cancer.

W hy is cell death beneficial in certain contexts, but not others? Obviously, the answer to this question is dependent on the developmental status of the tissue and may have to do with the tissue's ability to replace dead cells. In general, cells in proliferating tissues are readily replaced after tissue damage, whereas cells in differentiated tissue are much harder to renew, although examples have been reported (see below). The reason for this difference is obvious. Because cells in differentiated tissues are largely postmitotic, only a few cells will be able to reenter the cell cycle up on loss of vital cells. However, the ability to replace dying cells in proliferating tissues is so robust that cell death phenotypes are often overlooked. For example, in classical studies in Drosophila, it was observed that ionizing radiation induces massive cell death during larval stages, but that the emerging flies appear largely normal-because of compensatory proliferation (CP) (Haynie and Bryant 1977; Jaklevic and Su 2004; Perez-Garijo et al. 2004). Also, experimentally induced homozygous patches of cell lethal mutations eliminate a significant fraction of cells, often without any obvious effect on tissue size or morphologybecause of CP (Stowers and Schwarz 1999; Newsome et al. 2000). In another dramatic example, it was found that massive cell death caused by Ricin expression in one lineage-

Editors: Eric H. Baehrecke, Douglas R. Green, Sally Kornbluth, and Guy S. Salvesen

Additional Perspectives on Cell Survival and Cell Death available at www.cshperspectives.org

Copyright (C) 2012 Cold Spring Harbor Laboratory Press; all rights reserved; doi: 10.1101/cshperspect.a008797

Cite this article as Cold Spring Harb Perspect Biol 2012;4:a008797 
restricted compartment of the Drosophila wing imaginal discs triggered cells in the neighboring compartment to undergo enhanced cell proliferation, suggesting that a diffusible mitogenic signal is being emitted from the dying compartment (Milan et al. 1997). The ability to replace lost cells through CP appears to be conserved in mammals as well. When mice are subject to ionizing irradiation, actively proliferating cells such as those of the hematopoietic lineage or of the digestive system undergo massive cell death (Down et al. 1991). Although the loss of large numbers of cells compromise the health of these animals in the short term, those cells are quickly replenished to restore tissue function. In fact, if the ensuing cell death is blocked, for example through the disruption of p53, the animals suffer from deleterious consequences like cancer

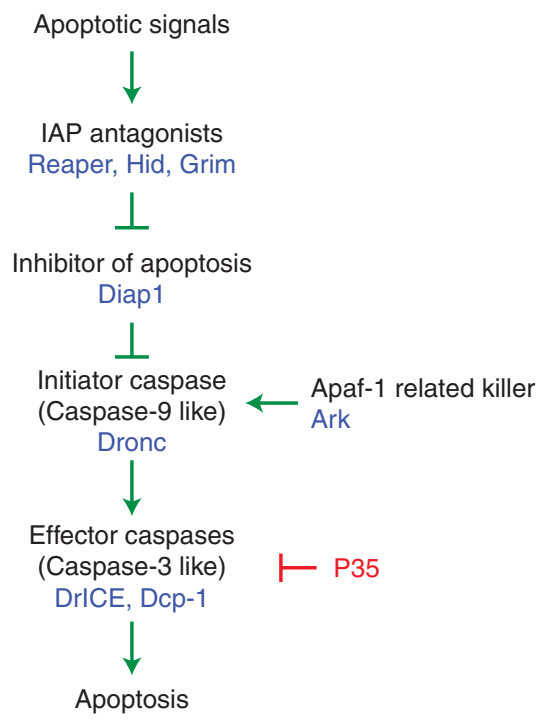

Figure 1. The apoptosis pathway in Drosophila. In living cells, the Caspase-9-like initiator caspase Dronc is inhibited by Drosophila inhibitor of apoptosis protein 1 (Diap1). Apoptosis is induced by activation of the IAP-antagonists Reaper, Hid, and Grim that induce ubiquitylation and degradation of Diap1. Dronc is released from Diap1 inhibition and forms the apoptosome holoenzyme together with the adaptor protein Ark. Dronc is activated in this complex, thereby proteolytically activating effector caspases DrICE and Dcp-1 causing apoptosis. The Baculovirus caspase inhibitor P35 acts specifically on DrICE and Dcp-1.
(Vousden 2000). This indicates that cell death serves as a beneficial quality control mechanism.

More recent work has shown that-at least in some cases-CP requires cell death-inducing genes, most notably caspases (Fan and Bergmann 2008a; Galliot and Chera 2010). Therefore, we refer to the induction of $\mathrm{CP}$ by apoptotic caspases specifically as "apoptosis-induced proliferation" and such examples will be extensively reviewed in this article.

Apoptosis-induced proliferation is beneficial for the organism, as it allows tissues to easily eliminate damaged or potentially dangerous cells and replace them with the progeny of healthy neighbors. When such compensatory mechanisms are no longer available, apoptosis may lose its beneficial effect to the body. In this review, we discuss recent progress in our understanding of how apoptosis can trigger proliferation. Special emphasis will be put on the role of apoptotic caspases in this process.

\section{CASPASES ARE CRITICAL EXECUTIONERS OF APOPTOSIS}

Across phyla, caspases are known as critical executioners of apoptosis. These proteins belong to a family of cysteine proteases that proteolytically cleave substrates after aspartic acid residues. Although their activity can be deadly, most cells containing these proteins do not die because caspases are synthesized as inactive zymogens. These proteases gain catalytic activity mostly on activation by upstream apoptotic signals (Thornberry and Lazebnik 1998). Caspases can be divided into initiator and effector caspases (Fig. 1). Initiator caspases, such as Caspase-8, Caspase-9, and Drosophila Dronc are characterized by long prodomains, which carry protein interaction motifs for upstream apoptotic signaling (Kumar 2007). Activated initiator caspases cleave and activate effector caspases such as Caspase-3, Caspase-7, and Drosophila DrICE and Dcp-1 (Fig. 1). Effector caspases are thought to cleave a large number of downstream substrates that collectively bring about the morphological features of apoptotic cells (Kerr et al. 1972; Dix et al. 2008; Mahrus et al. 2008). Elimination of caspases abolishes most apoptosis in 
model organisms such as Caenorhabditis elegans and Drosophila (Yuan et al. 1993; Chew et al. 2004; Daish et al. 2004; Xu et al. 2005, 2006). Likewise, knockout of caspases in mice significantly reduces the amount of cell death in that organism (Colussi and Kumar 1999). Given the importance of caspases in apoptosis, blocking their function is a good way to test whether cell death has a causal effect in triggering CP. A number of studies in various contexts have shown that, indeed, this is the case.

\section{THE ROLE OF CASPASES FOR COMPENSATORY PROLIFERATION IN DROSOPHILA}

It is clear that, in many tissues, injury-provoked cell death is accompanied by CP. Conceptually, this can happen through at least two ways. One possibility is that injury-provoked signaling may induce apoptosis-independent pathways that contribute to CP. Alternatively, proliferation is directly "instructed" by the dying cells. There is a considerable amount of data supporting the latter concept.

Genetic studies in Drosophila have identified two distinct pathways for apoptosis-induced proliferation, which require different sets of caspases. The first pathway requires the initiator caspase Dronc, but is independent of effector caspases. We will henceforth refer to this as the effector caspase-independent pathway of apoptosis-induced proliferation. This pathway and the independence of effector caspases was discovered in studies of "undead" cells (Huh et al. 2004; Perez-Garijo et al. 2004; Ryoo et al. 2004), in which cell death is initiated, but its execution is blocked by expression of the caspase inhibitor P35 (Clem et al. 1991; Xue and Horvitz 1995). In Drosophila, P35 specifically inhibits the effector caspases DrICE and Dcp-1, but not the initiator caspase Dronc (Fig. 1) (Hawkins et al. 2000; Meier et al. 2000). Thus, undead cells activate Dronc, but cannot execute apoptosis because of effector caspase inhibition by P35. Such undead cells caused hyperplastic growth (Fig. 2), most likely because of the persistence of mitogenic signals that would have otherwise been short-lived, if cells were allowed to undergo a natural course of cell death. Because P35 does not inhibit Dronc, this experimental setup revealed a nonapoptotic role of Dronc in inducing proliferation of neighboring cells (Fig. 3A). Such role of Dronc in growth
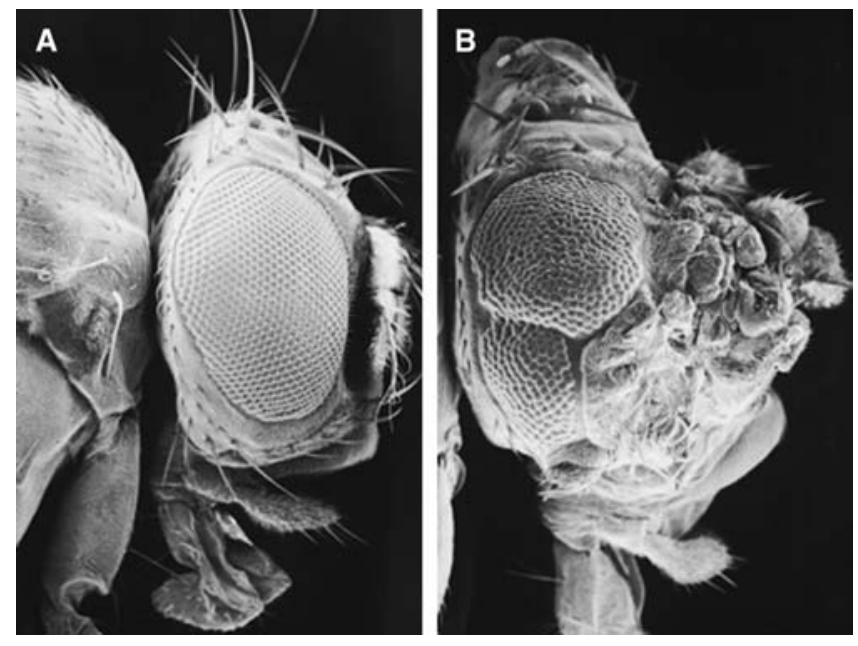

Figure 2. Hyperplastic overgrowth by undead cells. Scanning EM photographs showing eyes and heads from a normal fly $(A)$ and a fly containing a large number of undead cells in the head $(B)$. The head capsule in $B$ is strongly overgrown. The eye in $B$ is reduced in size because of increased wingless signaling that inhibits eye formation. Genotype in B: ey-Flp; tub $>$ GFP > Gal4; UAS-hid UAS-p35 (> marks FLP recognition target sites). 
H.D. Ryoo and A. Bergmann
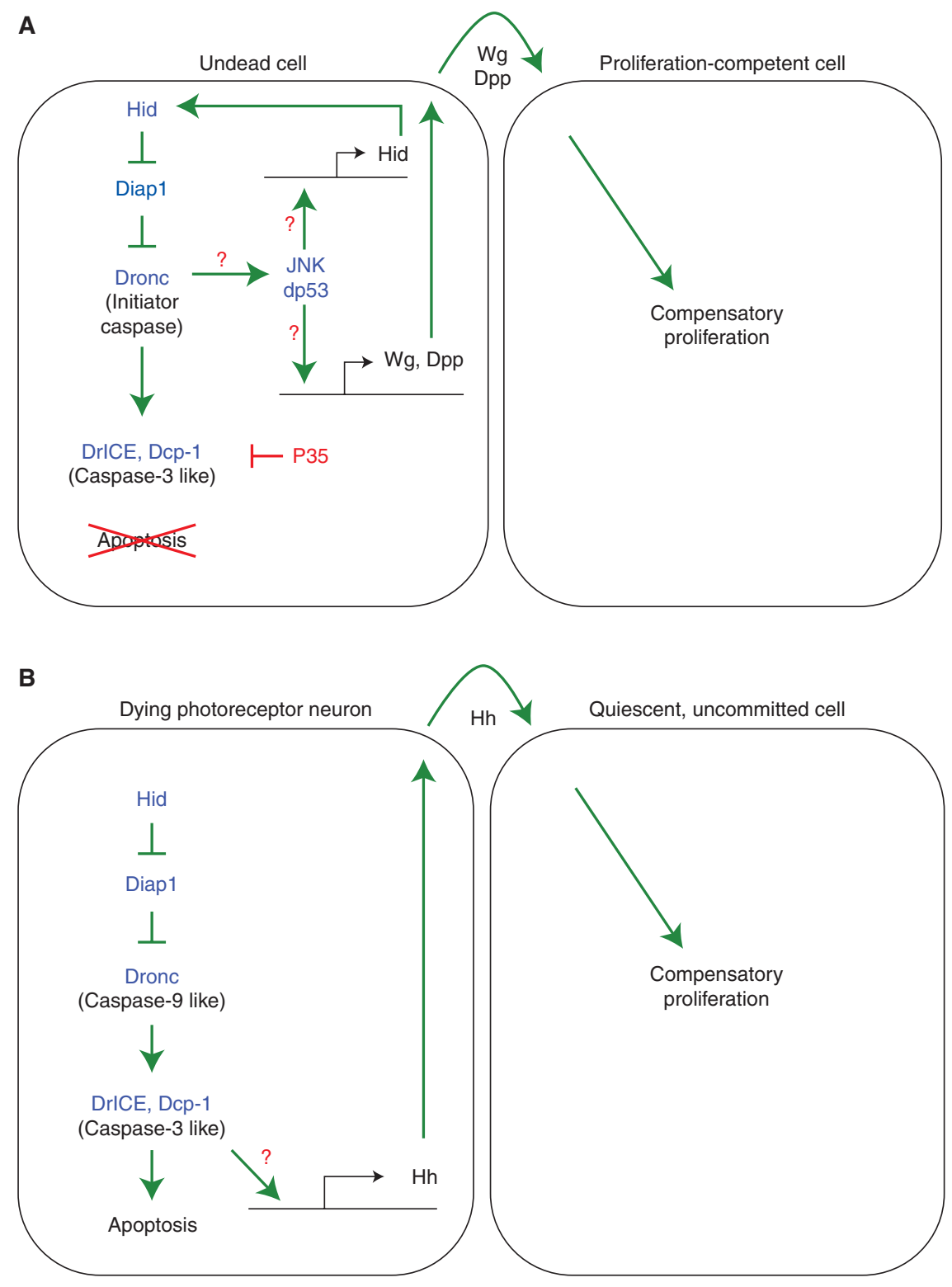

Figure 3. Distinct types of apoptosis-induced proliferation in Drosophila. $(A)$ The effector caspase-independent pathway. Induction of apoptosis in the presence of P35 produces undead cells because of effector caspase inhibition. The initiator caspase Dronc remains active in undead cells and stimulates the Jun N-terminal kinase (JNK) pathway. JNK together with Drosophila p53 (dp53) induces expression of the IAP antagonist Hid, establishing a positive feedback loop of apoptosis amplification. JNK and dp53 also stimulate the expression of the mitogens Wg and Dpp that promote neighboring cells to undergo compensatory proliferation. This mechanism leads to hyperplastic overgrowth shown in Figure 2. Question marks denote points of uncertainty. $(B)$ The effector caspase-dependent pathway. Expression of the IAP antagonist Hid in the postmitotic, differentiating field of the eye retina induces apoptosis. However, dying photoreceptor neurons are able to induce expression of the mitogen Hedgehog $(\mathrm{Hh})$, which stimulates neighboring cells that are postmitotic, but have not initiated a differentiation program (uncommitted) to reenter the cell cycle and undergo compensatory proliferation. This pathway is mediated by the effector caspases DrICE and Dcp-1. Expression of P35 does block this type of apoptosis-induced proliferation. Question marks denote open questions. 
promotion was directly confirmed by dronc mutants or dominant negative Dronc constructs (Huh et al. 2004; Kondo et al. 2006).

The second pathway of apoptosis-induced proliferation is used in a different developmental context and is dependent on effector caspases (hence, we refer to it as effector caspase-dependent apoptosis-induced proliferation pathway) (Fig. 3B). In contrast to the effector caspase-independent pathway, expression of P35 does inhibit apoptosis-induced proliferation in this context, as do double mutants of the effector caspases $d r I C E$ and $d c p$-1, again illustrating a direct requirement of caspases for apoptosis-induced proliferation (Fan and Bergmann 2008a,b). Therefore, blocking effector caspases has different effects on these two forms of apoptosis-induced proliferation. In the first case, it causes overgrowth (Fig. 2) with potential relevance for cancer; in the second one, it blocks apoptosis-induced proliferation, which has severe consequences for regenerative growth.

Why are there at least two distinct mechanisms of apoptosis-induced proliferation? The difference may lie in the developmental state of the apoptotic tissue. The effector caspase-independent pathway occurs in the proliferating regions with largely undifferentiated cells of wing and eye imaginal discs, whereas the effector caspase-dependent pathway is employed in postmitotic eye tissue containing many differentiating cells (Fan and Bergmann 2008b). Nevertheless, in the latter, although postmitotic, only cells that have not initiated a differentiation process can be induced to reenter the cell cycle. Differentiating cells such as photoreceptor neurons have lost the ability to reenter the cell cycle. In fact, differentiating photoreceptor neurons are the cells that emit mitogenic signals for apoptosisinduced proliferation of unspecified, yet postmitotic cells (Fan and Bergmann 2008b).

\section{THE ROLE OF CASPASES FOR REGENERATIVE GROWTH IN VARIOUS MODEL ORGANISMS}

In addition to the pioneering studies in Drosophila, the requirement of caspases for proliferation in regenerative growth has been shown in
Apoptosis-Induced Compensatory Proliferation

several regeneration models. The freshwater polyp Hydra is a classical model famously studied by eighteenth century zoologist Abraham Trembley, who showed that this animal has a remarkable regenerative capacity. When Hydra polyps were cut into half, he found that the two parts grow back to perfect polyps: the foot fragment grows a head, and the head fragment a foot (Trembley 1744). Only head regeneration requires new proliferation. Correlating with this, only the head-regenerating tip induces apoptosis at the amputation site in an Erk/ MAPK-dependent manner (Chera et al. 2009, 2011; Galliot and Chera 2010). Importantly, if cell death was blocked with an effector caspase inhibitor, cell proliferation and head regeneration was impaired, demonstrating an essential requirement of caspases for regenerative growth in this organism (Fig. 4). Moreover, these investigators took the analysis a step further and caused ectopic apoptosis in the foot-regenerating tip. Strikingly, this treatment not only induced cell proliferation, but changed the regeneration program from foot to head, resultingremarkably-in an ectopic head (Chera et al. 2009; Galliot and Chera 2010). These experiments underscore the requirement of apoptotic caspases for regenerative growth.

Similar observations have been made in vertebrates as well. The Xenopus tadpole is able to regenerate its tail after amputation. Twelve hours after amputation, apoptotic cells are detected at the site of injury. The regeneration of the lost tissue is dependent on the presence of these apoptotic cells, as effector caspase inhibitors block the ensuing cell proliferation and overall tissue regeneration (Fig. 4) (Tseng et al. 2007).

Mouse embryonic fibroblasts (MEFs) also have similar properties. A recent study has found that unstressed stem cell populations are stimulated to divide when mixed with MEFs that have been exposed to a lethal dose of irradiation. As in other organisms, this growth-promoting property of irradiated MEFs can be attributed to effector caspases, as eliminating Caspase- 3 and Caspase-7 function blocks stem cell growth ( $\mathrm{Li}$ et al. 2010). Furthermore, in intact animals, wound healing and liver regeneration after partial hepatectomy are dependent on Caspase-3 
H.D. Ryoo and A. Bergmann

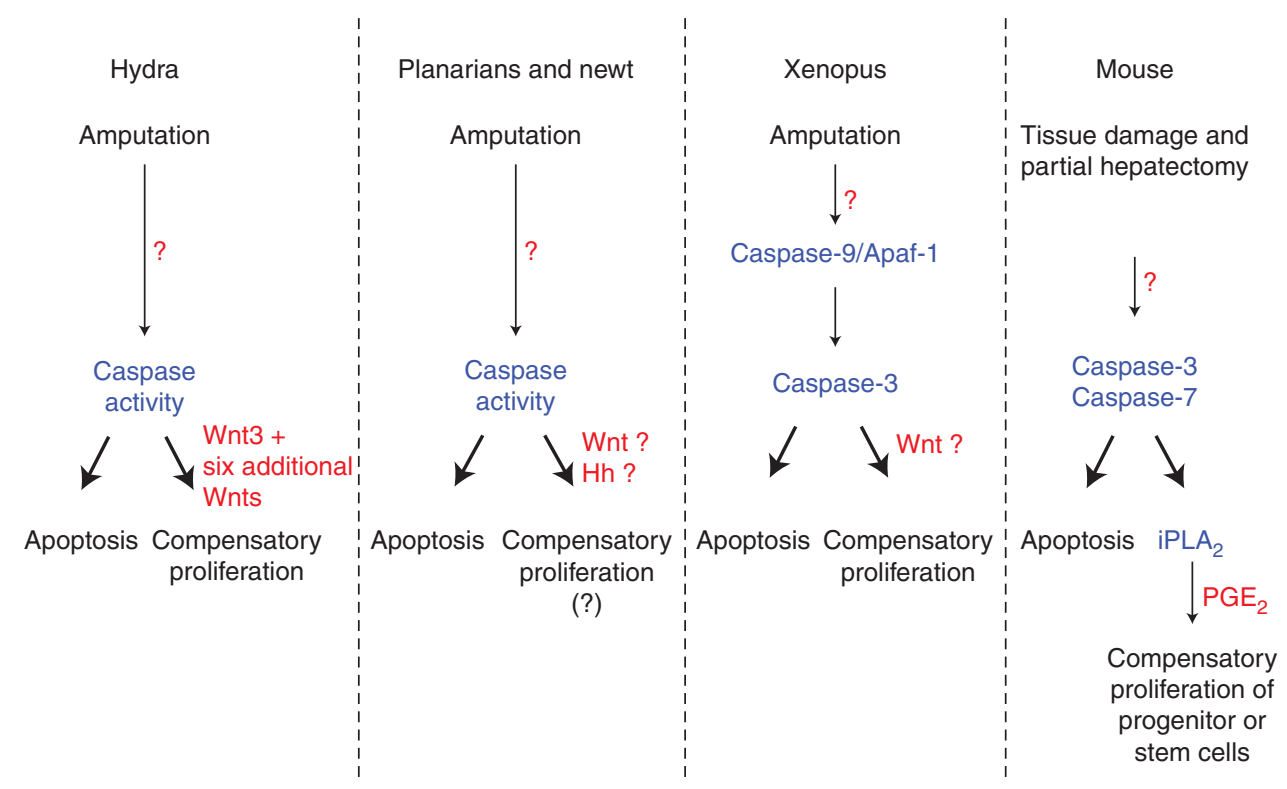

Figure 4. Effector caspases stimulate regeneration in several model organisms. Schematic summary of the experiments in several model organisms establishing a role of apoptotic caspases for regenerative growth. In most of these cases, this type of apoptosis-induced proliferation is effector caspase-dependent. Inhibition of effector caspases blocks regeneration. For details, see text. Question marks denote points of uncertainty.

and Caspase-7, because targeted inactivation of these caspases inhibits these regenerative processes (Fig. 4) (Li et al. 2010).

Therefore, similar to the observations made in Drosophila, these experiments suggest that apoptotic cells play an active role, possibly instructing the neighboring cells to undergo cell proliferation for regenerative processes and establish a causal role of apoptotic caspases in this process. In each of these cases, effector caspases were either inhibited or targeted by gene inactivation, resulting in loss of regeneration. This is similar to the second pathway of apoptosis-induced proliferation identified in Drosophila.

\section{IS THERE ENOUGH TIME FOR APOPTOTIC CELLS TO EXPRESS MITOGENS?}

Caspases are executioners of apoptosis that can dismantle a cell within hours. Is there really enough time for caspases to induce the transcription of mitogens, that would in turn, become translated in the cytoplasm, and then travel through the secretory pathway? A careful analysis of the literature suggests that, in fact, the kinetics of cell death do not appear so rapid that gene expression would be prohibited.

Caspases are well known for their ability to rapidly execute cell death. This is certainly the case when researchers inflict their cells with strong death stimulus, leading to full-blown caspase activation in a short period of time. However, it is also clear that many cells have subthreshold caspase activity that does not kill cells. This is well documented when fluorescent caspase sensors are expressed in living cells. Clearly, caspase activity is detected in cells that remain healthy (Kanuka et al. 2005). In addition, there is evidence of Dronc activity in living cells of Drosophila. This initiator caspase can be activated by its adaptor protein Ark (ortholog of Apaf-1 in mammals) (Fig. 1), which forms the multimeric apoptosome complex that serves as a platform to activate the initiator caspase Dronc (Yu et al. 2006). However, overexpression of Ark does not trigger apoptosis in vivo. Instead, it mildly activates Dronc activity that leads to Dronc protein instability (Shapiro 
et al. 2008). These experiments show that caspases can be active to perform certain functions without inducing apoptosis. Low levels of caspase activity in fact plays various nonapoptotic roles, including sensory neuron development (Geisbrecht and Montell 2004; Kanuka et al. 2005; Kuranaga et al. 2006; Oshima et al. 2006; Ouyang et al. 2011), cell migration (Geisbrecht and Montell 2004), cytoskeletal rearrangements (Kuranaga et al. 2006), spermatid differentiation (De Maria et al. 1999; Arama et al. 2003; Huh et al. 2004; Arama et al. 2007; Bader et al. 2011), and cell fate decision (De Maria et al. 1999; and reviewed by Miura 2012). Together, these observations indicate that caspase activity can be maintained below the threshold of apoptosis execution, and conceptually, this may allow cells to signal for proliferation prior to the onset of the rapid cell death program.

Even when cells increase caspase activity to trigger apoptosis, there may be a significant lag period. In Drosophila, cell death is initiated by IAP-antagonists, Reaper, Hid, and Grim (Fig. 1). These proteins directly bind and antagonize Diap1, which in turn directly inhibits the caspases Dronc and DrICE. Although the initial reports indicated that Reaper, Hid, and Grim are sufficient to initiate apoptosis (Grether et al. 1995; Chen et al. 1996; White et al. 1996), more recent evidence indicates that they require downstream signaling. These include the observation that Reaper activates JNK signaling, and without this downstream signaling event, Reaper remains as a poor inducer of apoptosis (Igaki et al. 2002; Shlevkov and Morata 2012). Independent observations report that overexpression of one IAP-antagonist leads to the transcriptional activation of another (Sandu et al. 2010), implying that these proteins induce a transcriptional response to further enhance caspase activity. In fact, overexpressed IAP-antagonists are poor killer proteins on their own, without the transcriptional induction of other endogenous IAP-antagonists (Sandu et al. 2010).

These observations paint a picture of the events that precede apoptosis and apoptosisinduced proliferation. The literature suggests that apoptosis is initiated by the expression of a small amount of apoptosis-initiating proteins.
This could be the IAP-antagonists in Drosophila, and BH3-only domain proteins or death ligands in mammals. The initial expression of such proapoptotic protein is not enough for a full-blown caspase activation for apoptosis, but sufficient to induce a signaling pathway that can orchestrate cell death and proliferation. In the case of Drosophila, this pathway is mediated by JNK and p53, which in turn has two different sets of transcriptional targets. One set are the proapoptotic genes for apoptosis, and the other set are mitogens that instruct proliferation (Fig. $3 \mathrm{~A})$. In such a scenario, there is plenty of time for apoptotic cells to induce proliferation. These considerations raise the next question: How do caspases induce proliferation?

\section{SIGNALING PATHWAYS WITHIN DYING CELLS: THE ROLE OF JNK SIGNALING}

First clues about the signaling pathways involved in apoptosis-induced proliferation came from genetic studies in Drosophila. Key for this analysis was to keep dying cells in an undead condition by P35 expression. In these cells, signaling pathways and mitogen expression persists in making their identification possible. This treatment helped gain mechanistic understanding of the effector caspase-independent pathway of apoptosis-induced proliferation, in which Dronc initiates the proliferation response (Fig. 3A) (Huh et al. 2004; Perez-Garijo et al. 2004; Ryoo et al. 2004).

How does Dronc induce proliferation? The principle mediator of apoptosis-induced proliferation is JNK signaling (Ryoo et al. 2004). In fact, activation of JNK signaling independently of apoptosis is sufficient for induction of proliferation (Fig. 3A) (Perez-Garijo et al. 2005, 2009; Smith-Bolton et al. 2009; Bergantinos et al. 2010; Warner et al. 2010; Suissa et al. 2011). However, JNK activity is also tightly associated with stress and apoptosis. As such, JNK signaling acts upstream of the apoptotic pathway and can induce the expression of proapoptotic genes (Moreno et al. 2002). Therefore, JNK signaling acts both upstream and downstream from the apoptotic pathway, forming a feedforward loop for apoptosis amplification under 
stress conditions (Fig. 3A) (Wells et al. 2006; Shlevkov and Morata 2012). Supporting this notion, JNK markers are autonomously induced in undead cells, and tissue growth can be blocked when a JNK inhibitor is overexpressed (Ryoo et al. 2004). Because of this strong proapoptotic effect of JNK signaling, its role in apoptosis-induced proliferation can only be uncovered if cells are rendered undead by effector caspase inhibition such as P35. Nevertheless, JNK induced in undead cells requires Dronc, as this pathway is blocked in dronc mutant cells (Kondo et al. 2006; Wells et al. 2006; Shlevkov and Morata 2012). How Dronc activates JNK for apoptosis-induced proliferation is currently unknown, but evidence for nonapoptotic substrates of Dronc has been provided (Fan and Bergmann 2010).

In addition to JNK, Drosophila p53 (Dp53) was found to be required for the Dronc/JNK amplification loop and for growth of undead tissue (Fig. 3A) (Wells et al. 2006; Wells and Johnston 2012). Similarly, a planarian p53 ortholog has been implicated in stem cell renewal and proliferation (Pearson and Sanchez Alvarado 2010). The function of Dp53 for apoptosisinduced proliferation is independent of the DNA-damage sensing pathway as the DNAdamage checkpoint genes atm and chk2 are not required for proliferation (Wells et al. 2006). Both JNK and Dp53 constitute a positive feedback loop that leads to activation of hid and reaper expression (Fig. 3A) (Brodsky et al. 2000; Wells et al. 2006; Fan et al. 2010; Shlevkov and Morata 2012; Wells and Johnston 2012). How p53 affects JNK signaling remains unclear, but a recent study provides a possible mechanistic basis. In both humans and Drosophila, p53 physically binds to phosphorylated JNK, thereby protecting them from the inactivating phosphatases (Gowda et al. 2012). Based on these observations, it is most likely that the p53/JNK complex serves as a signaling mediator that connects Dronc activation in the cytoplasm to gene expression in the nucleus.

The intracellular signaling events in the second effector caspase-dependent pathway of apoptosis-induced proliferation are unknown, except that it requires the effector caspases DrICE and Dcp-1 (Fig. 3B) (Fan and Bergmann 2008b). JNK and Dp53 are not involved in this pathway, which poses an interesting problem, because Dronc is also necessary for this type of proliferation. Why Dronc does not activate JNK signaling in this context is unknown.

\section{MITOGEN SIGNALING FOR COMPENSATORY PROLIFERATION IN DROSOPHILA}

How are apoptotic cells actively signaling to the surviving neighbors to undergo compensatory cell proliferation? For such signaling to occur, the apoptotic cell must express a secretory mitogen, or at least a membrane anchored ligand that can instruct the neighboring cells to undergo extra proliferation. Now, there are a number of well-documented studies indicating that this is indeed the case.

Again, early evidence that apoptotic cells induce mitogens came from studies in Drosophila. The proliferation pathway in P35-expressing undead cells induces the expression of the Wnt family member wingless and the TGF- $\beta$ /BMP member $d p p$ (Fig. 3A) (Huh et al. 2004; Perez-Garijo et al. 2004; Ryoo et al. 2004), which encode secretory proteins with strong mitogenic properties. At least in the wing imaginal discs, wingless and $d p p$ were attributable to the overgrowth phenotype as elimination of these genes blocked abnormal growth (Perez-Garijo et al. 2005, 2009). These results can be most simply interpreted by the fact that P35 is not able to block Dronc, which is responsible for nonautonomous proliferation (Fig. $3 \mathrm{~A})$. Although most of the experiments were performed in a rather artificial setup in which cell death was inhibited by P35, mitogen expression was confirmed in settings where apoptotic cells were allowed to undergo its natural death course as well (Perez-Garijo et al. 2004; Ryoo et al. 2004; Smith-Bolton et al. 2009). In addition, such expression of mitogens can explain how apoptosis can fuel proliferation.

Although developmentally older tissues, especially after completion of the cell proliferation phase, are less able to compensate for cell loss (Smith-Bolton et al. 2009), the second form of 
apoptosis-induced proliferation in Drosophila, effector caspase-dependent proliferation, was observed in a largely postmitotic tissue. This tissue is the differentiating retina in the Drosophila eye during late larval stages. At that stage, a large number of postmitotic cells has formed, which will be instructed to differentiate first into photoreceptor neurons followed by cone, pigment, and bristle cells in a very specific temporal order (Voas and Rebay 2004). When apoptosis is induced in this tissue, proliferation is induced as well. However, this proliferation is restricted to cells that have not initiated differentiation yet (Fan and Bergmann 2008b) suggesting that these cells-although postmitotic under normal conditions-are still competent to reenter the cell cycle. Differentiating cells such as photoreceptor neurons do not reenter the cell cycle under apoptotic conditions and may have lost mitotic potential.

However, dying photoreceptor neurons produce and secrete Hedgehog ( $\mathrm{Hh})$, which is the mitogen for apoptosis-induced proliferation in this system (Fig. 3B) (Fan and Bergmann 2008b). Interestingly, the postmitotic cells do not respond to $\mathrm{Hh}$ signaling immediately. It takes them about $6-12 \mathrm{~h}$ before they reenter the cell cycle. The reason for this delay is unknown, but it is very similar to the time it takes quiescent cells in mammals to become mitotically active again (Coller 2007). Thus, genetic studies in Drosophila may uncover mechanisms of cell cycle reentry, which may be very relevant for mammalian cells and tumor initiation.

The genes required in the surviving, proliferating cells are less well characterized. In an approach to identify such genes, Hariharan and colleagues conducted an unbiased genetic screen (Gerhold et al. 2011). They analyzed the ability of tissues to recover size after massive apoptosis was triggered by a temperature-sensitive cell lethal mutation under nonpermissive conditions. They reported that mutations in the genes Ribonucleoside diphosphate reductase large subunit (RnrL), the GDP-mannose 4, 6 dehydratase $G m d$, and the putative transcription factor bunched (bun) specifically affect CP without affecting growth under normal conditions (Gerhold et al. 2011). As yet, how these genes affect CP remains to be elucidated. It is also unknown whether apoptotic cells trigger the surviving cells to proliferate, i.e., whether this is a form of apoptosis-induced proliferation.

\section{MITOGEN SIGNALING FOR APOPTOSIS- INDUCED PROLIFERATION IN OTHER REGENERATION MODELS}

Since the original reports from Drosophila, a number of studies have established that the ability of apoptotic cells to induce mitogen expression is conserved across phyla and involves signals of the Wnt, TGF- $\beta$, and Hh families. In the Hydra regeneration model, it was shown that apoptotic cells express Wnt3, a homolog of the Drosophila wingless gene, and blocking Wnt3 induction indeed impairs head regeneration (Chera et al. 2009; Galliot and Chera 2010). Interestingly, Wnt3 initiates a Wnt cascade that involves six additional Wnt signaling factors for head regeneration (Fig. 4) (Lengfeld et al. 2009). In other models of regeneration, such as planarians and newt, Wnt, TGF- $\beta$, and Hh signaling have been implicated in regeneration responses (Fig. 4) (Reddien et al. 2007; Gurley et al. 2008; Petersen and Reddien 2008, 2009; Rink et al. 2009). In these animals, induction of massive apoptosis has been observed at the amputation site (Hwang et al. 2004; Vlaskalin et al. 2004; Pellettieri and Sanchez Alvarado 2007), but it is unknown at present whether apoptotic cells are the source of the regenerating mitogens.

In vertebrates, Wnt signaling is also critical for regeneration, but its function is more complex and can have even opposing functions. For example, fin regeneration in zebrafish is enhanced by Wnt8 expression, but suppressed by Wnt5b (Stoick-Cooper et al. 2007). In addition to Wnt signaling, prostaglandin E2 (PGE2) has also been implicated in apoptosis-induced proliferation (Fig. 4). In zebrafish, the hematopoietic lineage readily undergoes cell death after irradiation. However, when these fish are treated with a stabilized derivative of PGE2, hematopoietic stem cells and bone marrow recovery is enhanced (North et al. 2007). The role of PGE2 in apoptosis-induced proliferation was further validated in a mouse model ( $\mathrm{Li}$ et al. 2010). The 
investigators of that study used a cell culture system in which various stem cells were incubated with stressed or nonstressed MEFs. They found that the stem cells grew faster only when the coincubated MEFs were previously exposed to a lethal dose of ionizing irradiation. Furthermore, the growth boosting activity from apoptotic MEFs was dependent on Caspase- 3 and Caspase-7. Under these conditions, Caspase-3 and Caspase-7 activate calcium-independent phospholipase A2 (iPLA2), an enzyme in the pathway of PGE2 synthesis (Fig. 4). Consistently, knockdown of iPLA2 impairs the ability of apoptotic cells to stimulate apoptosis-induced proliferation (Li et al. 2010).

These reports establish the importance of Wnt and PGE2 in apoptosis-induced proliferation. In fact, Wnt and PGE2 signaling are intimately linked. Hints to a relationship were revealed in the 1990s through the analysis of $\mathrm{APC}^{\mathrm{min}}$ mice, in which unrestrained Wnt signaling underlies the development of innumerable colonic polyps and ultimately colon cancer. Such formation of polyps is inhibited when prostaglandin biosynthesis is impaired (Giardiello et al. 1993). This relationship is also conserved in hematopoietic stem cells (HSC). These cells are particularly well known for their ability to repopulate after irradiation-induced apoptosis. In the regenerating HSCs, Wnt-induced $\beta$-catenin signaling and PGE2 are required. In fact, PGE2 treatment activates Wntresponsive reporters within the regenerating HSCs. Espistatic experiments show that PGE2 regulates Wnt signaling by controlling the cAMP/PKA pathway (Goessling et al. 2009).

Although these studies have established the importance of mitogenic signaling that originates from apoptotic cells, many details remain to be worked out. For example, there remains some disagreement about the role of wingless in apoptosis-induced proliferation in Drosophila. In one particular study, where regeneration capacity after massive cell death was analyzed, it was shown that RNAi-mediated knockdown of wingless blocks cell proliferation associated with apoptosis (Smith-Bolton et al. 2009). In a different study, however, the tissue's ability to recover its size after X-ray irradiation-induced cell death was reportedly not affected by the loss of wingless (Perez-Garijo et al. 2009). Whether the role of wingless is dependent on the nature of the apoptotic stress, or the experimental setup remains to be resolved.

There is a possibility that other signaling proteins function redundantly with wingless (and $d p p$ ) in apoptosis-induced proliferation. Supporting this thought, a recent report has implicated a role of the Hippo/Yorkie pathway in apoptosis-induced proliferation. This is a growth regulatory pathway that is regulated by cell adhesion proteins and apico-basal polarity determinants (Bennett and Harvey 2006; Cho et al. 2006; Silva et al. 2006; Willecke et al. 2006; Chen et al. 2010; Grzeschik et al. 2010; Ling et al. 2010). Downstream from these factors are kinase complexes, represented by the Hippo kinase, and the transcription factor Yorkie. When Hippo signaling is active, Yorkie is phosphorylated and remains in the cytoplasm. This transcription factor translocates to the nucleus when the Hippo pathway is inactive, thereby inducing growth and antiapoptotic genes. Independent studies on Drosophila tissue regeneration have found that Yorkie translocates to the nucleus in the regenerating cells (Cai et al. 2010; Sun and Irvine 2011). Such regulation of Yorkie activity in living cells depends on JNK activity in dying cells (Sun and Irvine 2011). Thus, it is conceivable that JNK signaling in apoptotic cells induces a Hippo pathway ligand, in addition to other known mitogens.

\section{THE ROLE OF APOPTOSIS-INDUCED COMPENSATORY PROLIFERATION IN CANCER}

Evasion from apoptosis is one of the hallmarks of cancer (Hanahan and Weinberg 2000). Initially, the concept of "evasion from apoptosis" implied that tumor cells autonomously escape apoptotic signals either by the immune system or by therapeutic regimens (Hanahan and Weinberg 2000). However, the discovery of apoptosis-induced proliferation adds another layer to this concept, the nonautonomous induction of proliferation, which may have the opposite cancer-promoting activity. As outlined 
above, genetic studies in Drosophila have revealed two distinct types of apoptosis-induced proliferation. Of particular interest for cancer development is effector caspase-independent apoptosis-induced proliferation. In this case, undead cells generated by P35-mediated inhibition or genetic ablation of effector caspases promote overgrowth, which may contribute to tumor development. Many tumor cells have acquired at least some resistance to apoptosis and may resemble undead cells. They initiate the cell death program, but cannot or only slowly execute it, because an essential component of the cell death pathway is mutated or otherwise inhibited. For example, the breast cancer-derived MCF-7 cell line harbors an inactivating point mutation in the gene encoding the effector caspase Caspase-3 (Kurokawa et al. 1999). Furthermore, loss of Caspase- 3 mRNA and protein has been reported in samples from breast, ovarian, and cervical cancers, as well as neuroblastoma (Devarajan et al. 2002; Iolascon et al. 2003). Large-scale analysis of caspase genes in many different tumors reveal several alterations of Caspase- 3 and other caspases (reviewed by Ghavami et al. 2009). In addition, caspase inhibitors such as IAPs and c-FLIP are frequently overexpressed in cancer cells (Tamm et al. 2000; LaCasse et al. 2008; Yang 2008). Thus, in these cases, loss or inhibition of Caspase-3 may not only confer resistance to apoptosis-inducing chemotherapy, but these undead tumor cells may emit excessive amounts of mitogens and thus may cause even more severe tumor growth.

It is unknown whether Caspase-9, the mammalian ortholog of the initiator caspase Dronc, has a similar nonapoptotic function for cell proliferation. However, the CD95/Fas/Apo-1 extrinsic cell death pathway may have such a function. This pathway has been extensively studied for its apoptotic role. CD95 activation recruits FADD and Caspase-8 into the death-inducing signaling complex (DISC) that triggers apoptosis by activation of Caspase-3 (Fig. 5A) (Nagata 1999; Krammer 2000). However, CD95 can also promote proliferation and tumor growth in a nonapoptotic function (Fig. 5A) (OwenSchaub et al. 1993; Desbarats et al. 1999; Peter et al. 2007; Chen et al. 2010). Mouse models
Apoptosis-Induced Compensatory Proliferation

show that liver and ovarian cancers depend on CD95 function (Chen et al. 2010). CD95 has also been reported to be required for liver regeneration after partial hepatectomy (Desbarats and Newell 2000). In this case, liver regeneration is impaired in $l p r$ mice, which have reduced cell surface CD95. Interestingly, lpr-cg mutant mice that carry a point mutation in the death domain of CD95 rendering it unable to interact with FADD and induce apoptosis but is expressed at normal cell surface levels (Kimura and Matsuzawa 1994), have an even increased rate of regeneration (Desbarats and Newell 2000). This observation suggests that the apoptosis- and proliferation-promoting functions of CD95 can be uncoupled (Fig. 5A). It also suggests that inhibition of the apoptosis-promoting function of CD95 may augment the tumor-promoting function of CD95 as has been implied in ovarian cancer (Baldwin et al. 1999). For example, it is conceivable to speculate that inhibition of Caspase- 8 by c-FLIP unleashes the tumor-promoting function of CD95 (Safa and Pollok 2011; Jing et al. 2012). Interestingly, the proliferation- and tumor-promoting function of CD95 is mediated by JNK, Fos, and Egr1 (Fig. 5A) (Chen et al. 2010). The mechanism of JNK activation in this system is unknown, and may not involve caspases, but it illustrates the same principle as originally observed for apoptosis-induced proliferation in Drosophila (Huh et al. 2004; Ryoo et al. 2004).

Finally, not only undead tumor cells, but also "genuine" apoptotic tumor cells can promote apoptosis-induced proliferation. Recently, it was shown that tumor cells that were induced to die by radiotherapy stimulate tumor regrowth (Huang et al. 2011). In this case, dying tumor cells were not kept in an undead condition, but were able to secrete signaling molecules for tumor regrowth. In fact, Caspase-3 was required for tumor regrowth as Caspase-3 deficiency rendered the tumors more sensitive to radiotherapy. This proliferation- and tumorpromoting activity of Caspase-3 is mediated through cleavage and activation of cytosolic calcium-independent phospholipase A2 (iPLA2) that ultimately produces prostaglandin E2 (Fig. 4) (Li et al. 2010; Huang et al. 2011). 
H.D. Ryoo and A. Bergmann

A

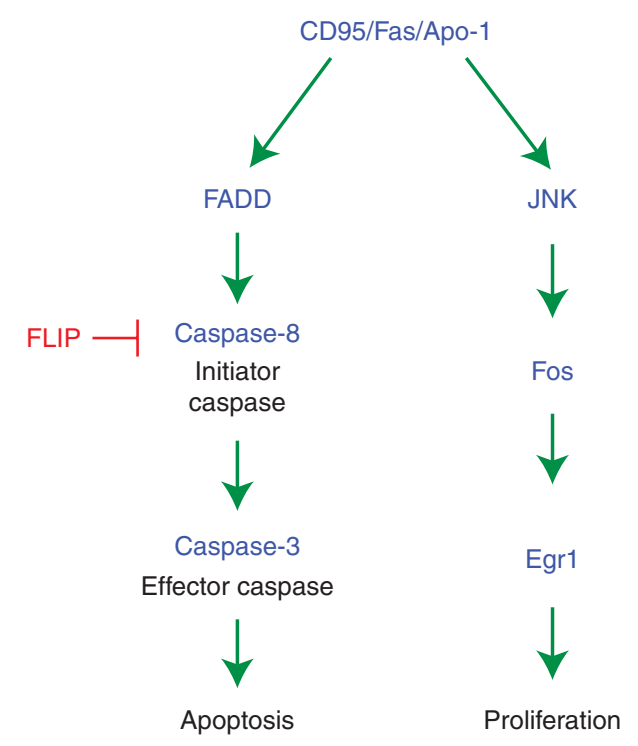

B
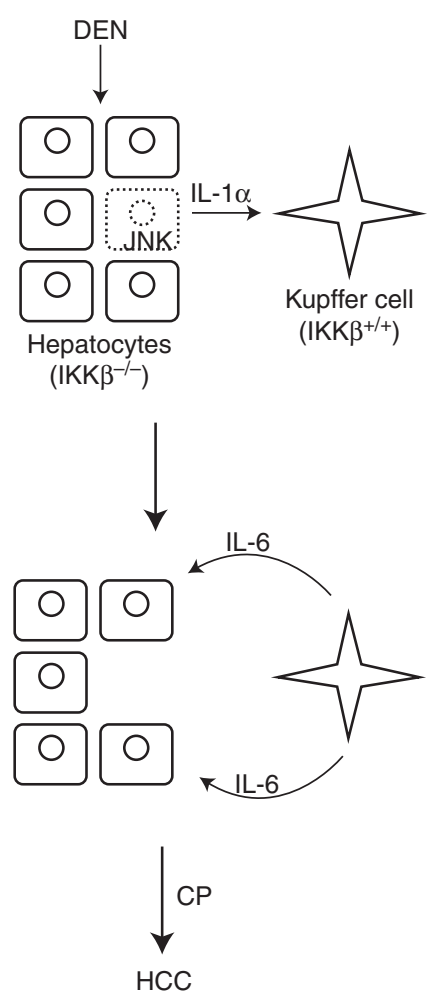

Figure 5. Potential models of apoptosis-induced proliferation in mammals. (A) The CD95/Fas/Apol pathway in apoptosis and proliferation. The CD95/Fas/Apo1 receptor induces apoptosis through the very well-studied FADD/Caspase- 8 pathway. FLIP is a Caspase- 8 analog and acts as a dominant negative for Caspase- 8 activation. The proliferation component of CD95/Fas/Apo1 is less characterized, but appears to engage the JNK pathway. (B) Role of compensatory proliferation for development of hepatocarcinoma (HCC). Loss of IKK $\beta$ or IKK $\gamma$ renders hepatocytes extremely sensitive to carcinogens such as diethylnitrosoamine (DEN), causing JNK-induced cell death (stippled cell). However, JNK also induces expression of interleukin-1 $\alpha$ (IL-1 $\alpha)$. IL-1 $\alpha$ induces the production of IL- 6 in Kupffer cells. IL- 6 feeds back onto surviving hepatocytes and induces proliferation and subsequently HCC. Interestingly, because IL- $1 \alpha$ induces NF- $\kappa$ B activation, Kupffer cells need to be wild-type for IKK $\beta$ and IKK $\gamma$ for apoptosis-induced proliferation and HCC to occur. (Panel based on data modified from He and Karin [2011].)

Therefore, radio- and chemotherapy may be ineffective or even counter-productive because apoptotic tumor cells can induce proliferation of surviving tumor cells. Moreover, the same investigators examined untreated tumor samples from patients with head and neck as well as advanced stage breast cancer for evidence of activated Caspase-3. Surprisingly, samples with high levels of activated Caspase-3 correlated with higher recurrence and shorter survival times of the patients (Huang et al. 2011), consistent with the concept of apoptosis-induced proliferation. It is unknown how Caspase-3 is activated in these tumors.

Apoptosis-induced proliferation may also be the underlying cause of cell and tissue typespecific differences for tumor development. For example, NF-кB activation was found to be a tumor promoter in many tumors including colitis-associated cancer (CAC) and melanoma in mice (Greten et al. 2004; Yang et al. 2010). In contrast, loss of NF- $\kappa \mathrm{B}$ activity augments squamous cell carcinoma and carcinogen-induced hepatocellular carcinoma (HCC) (Dajee et al. 
2003; Maeda et al. 2005; Sakurai et al. 2008). At least for HCC, this difference may be explained by apoptosis-induced proliferation. The activity of NF-кB is controlled by the IKK complex, which targets ІкB for phosphorylation and degradation (Karin et al. 2006). IKK $\beta$ and IKK $\gamma$, the catalytic and regulatory subunits of IKK, are required for the survival of hepatocytes ( $\mathrm{Li}$ et al. 1999). Treatment of IKK $\beta^{-/-}$and IKK $\gamma^{-/-}$ hepatocytes with carcinogens such as diethylnitrosamine (DEN) causes accumulation of radical oxygen species (ROS) resulting in hepatocyte cell death, which triggers apoptosis-induced proliferation and HCC in the following manner (Fig. 5B) (Maeda et al. 2005; Sakurai et al. 2008). Dying hepatocytes increase JNK activity and release interleukin- $1 \alpha(\mathrm{IL}-1 \alpha)$ (Sakurai et al. 2008). IL-1 $\alpha$ stimulates Kupffer cells, which in turn secrete IL-6 (Maeda et al. 2005). Finally, IL-6 promotes proliferation of surviving hepatocytes causing HCC (Fig. 5B). Thus, Kupffer cells represent an intermediary step for apoptosis-induced proliferation. The common theme here is that dying cells cause apoptosisinduced proliferation and cancer through activation of JNK signaling, similar to Drosophila. However, the secreted mitogens and cytokines are different and may vary in a cell type-specific manner. Interestingly, IL- $1 \alpha$ stimulates IKK/ NF- $\mathrm{B}$ activity in Kupffer cells. Thus, if Kupffer cells are also IKK $\beta^{-/-}$and IKK $\gamma^{-/-}$, apoptosis-induced proliferation and HCC are blocked (Maeda et al. 2005), providing another example of cell type-specific differences regarding tumorigenesis.

These examples illustrate that apoptosis-induced proliferation may critically contribute to tumor development and tumor growth.

\section{CONCLUDING REMARKS}

The traditional view that apoptotic cells only display signals for engulfment at the cell surface, but otherwise shut down metabolically is an oversimplification. These cells are very capable of communicating with neighboring cells and prepare them for their departure. In this review, we focused on the ability of apoptotic cells to induce proliferation of surviving cells. This is
Apoptosis-Induced Compensatory Proliferation

directly dependent on apoptotic caspases and may have significant implications for wound healing and regeneration after tissue loss. Obviously, apoptosis-induced proliferation may be critical for tumor initiation and tumor development. However, apoptotic cells may also influence neighboring surviving cells in other ways. For example, while apoptotic cells die, they can increase the apoptotic resistance of neighboring cells in some cases (Herz et al. 2006). The mechanism of this process is much less understood, but will be of significance for the understanding of tumor development. It is also conceivable that apoptotic cells change the shape and size of surviving cells, induce cellular migration, or may even change their differentiation status. We expect that progress in these areas will have important clinical implications, especially for regenerative medicine and cancer.

\section{ACKNOWLEDGMENTS}

We would like to thank our colleagues, especially Hermann Steller and Yun Fan, for stimulating discussions and advice. This work is supported by grants from the National Institute of Health (NIH) GM068016 to A.B. and GM079425 and EY020866 to H.D.R.

\section{REFERENCES}

* Reference is also in this collection.

Arama E, Agapite J, Steller H. 2003. Caspase activity and a specific cytochrome $\mathrm{C}$ are required for sperm differentiation in Drosophila Dev Cell 4: 687-697.

Arama E, Bader M, Rieckhof GE, Steller H. 2007. A ubiquitin ligase complex regulates caspase activation during sperm differentiation in Drosophila. PLoS Biol 5: e251.

Bader M, Benjamin S, Wapinski OL, Smith DM, Goldberg AL, Steller H. 2011. A conserved F box regulatory complex controls proteasome activity in Drosophila. Cell 145: 371-382.

Baldwin RL, Tran H, Karlan BY. 1999. Primary ovarian cancer cultures are resistant to Fas-mediated apoptosis. $G y$ necol Oncol 74: 265-271.

Bennett FC, Harvey KF. 2006. Fat cadherin modulates organ size in Drosophila via the Salvador/Warts/Hippo signaling pathway. Curr Biol 16: 2101-2110.

Bergantinos C, Corominas M, Serras F. 2010. Cell deathinduced regeneration in wing imaginal discs requires JNK signalling. Development 137: 1169-1179. 
H.D. Ryoo and A. Bergmann

Brodsky MH, Nordstrom W, Tsang G, Kwan E, Rubin GM, Abrams JM. 2000. Drosophila p53 binds a damage response element at the reaper locus. Cell 101: 103-113.

Cai J, Zhang N, Zheng Y, de Wilde RF, Maitra A, Pan D. 2010. The Hippo signaling pathway restricts the oncogenic potential of an intestinal regeneration program. Genes Dev 24: $2383-2388$.

Chen P, Nordstrom W, Gish B, Abrams JM. 1996. grim, a novel cell death gene in Drosophila. Genes Dev 10: 17731782.

Chen L, Park SM, Tumanov AV, Hau A, Sawada K, Feig C, Turner JR, Fu YX, Romero IL, Lengyel E, et al. 2010. CD95 promotes tumour growth. Nature 465: 492-496.

Chera S, Ghila L, Dobretz K, Wenger Y, Bauer C, Buzgariu W, Martinou JC, Galliot B. 2009. Apoptotic cells provide an unexpected source of Wnt3 signaling to drive hydra head regeneration. Dev Cell 17: 279-289.

Chera S, Ghila L, Wenger Y, Galliot B. 2011. Injury-induced activation of the MAPK/CREB pathway triggers apoptosis-induced compensatory proliferation in hydra head regeneration. Dev Growth Differ 53: 186-201.

Chew SK, Akdemir F, Chen P, Lu WJ, Mills K, Daish T, Kumar S, Rodriguez A, Abrams JM. 2004. The apical caspase dronc governs programmed and unprogrammed cell death in Drosophila. Dev Cell 7: 897-907.

Cho E, Feng Y, Rauskolb C, Maitra S, Fehon R, Irvine KD. 2006. Delineation of a Fat tumor suppressor pathway. Nat Genet 38: 1142-1150.

Clem RJ, Fechheimer M, Miller LK. 1991. Prevention of apoptosis by a baculovirus gene during infection of insect cells. Science 254: 1388-1390.

Coller HA. 2007. What's taking so long? S-phase entry from quiescence versus proliferation. Nat Rev Mol Cell Biol 8: 667-670.

Colussi PA, Kumar S. 1999. Targeted disruption of caspase genes in mice: What they tell us about the functions of individual caspases in apoptosis. Immunol Cell Biol 77: $58-63$.

Daish TJ, Mills K, Kumar S. 2004. Drosophila caspase DRONC is required for specific developmental cell death pathways and stress-induced apoptosis. Dev Cell 7: 909-915.

Dajee M, Lazarov M, Zhang JY, Cai T, Green CL, Russell AJ, Marinkovich MP, Tao S, Lin Q, Kubo Y, et al. 2003. NF-кB blockade and oncogenic Ras trigger invasive human epidermal neoplasia. Nature 421: 639-643.

De Maria R, Zeuner A, Eramo A, Domenichelli C, Bonci D, Grignani F, Srinivasula SM, Alnemri ES, Testa U, Peschle C. 1999. Negative regulation of erythropoiesis by caspasemediated cleavage of GATA-1. Nature 401: 489-493.

Desbarats J, Newell MK. 2000. Fas engagement accelerates liver regeneration after partial hepatectomy. Nat Med 6: 920-923.

Desbarats J, Wade T, Wade WF, Newell MK. 1999. Dichotomy between naive and memory $\mathrm{CD} 4^{+} \mathrm{T}$ cell responses to Fas engagement. Proc Natl Acad Sci 96: 8104-8109.

Devarajan E, Sahin AA, Chen JS, Krishnamurthy RR, Aggarwal N, Brun AM, Sapino A, Zhang F, Sharma D, Yang $\mathrm{XH}$, et al. 2002. Down-regulation of caspase 3 in breast cancer: A possible mechanism for chemoresistance. $\mathrm{On}$ cogene 21: 8843-8851.
Dix MM, Simon GM, Cravatt BF. 2008. Global mapping of the topography and magnitude of proteolytic events in apoptosis. Cell 134: 679-691.

Down JD, Tarbell NJ, Thames HD, Mauch PM. 1991. Syngeneic and allogeneic bone marrow engraftment after total body irradiation: Dependence on dose, dose rate, and fractionation. Blood 77: 661-669.

Fan Y, Bergmann A. 2008a. Apoptosis-induced compensatory proliferation. The Cell is dead. Long live the Cell! Trends Cell Biol 18: 467-473.

Fan Y, Bergmann A. 2008b. Distinct mechanisms of apoptosis-induced compensatory proliferation in proliferating and differentiating tissues in the Drosophila eye. Dev Cell 14: 399-410.

Fan Y, Bergmann A. 2010. The cleaved-Caspase-3 antibody is a marker of Caspase-9-like DRONC activity in Drosophila. Cell Death Differ 17: 534-539.

Fan Y, Lee TV, Xu D, Chen Z, Lamblin AF, Steller H, Bergmann A. 2010. Dual roles of Drosophila p53 in cell death and cell differentiation. Cell Death Differ 17: 912-921.

Galliot B, Chera S. 2010. The Hydra model: Disclosing an apoptosis-driven generator of Wnt-based regeneration. Trends Cell Biol 20: 514-523.

Geisbrecht ER, Montell DJ. 2004. A role for Drosophila IAP1-mediated caspase inhibition in Rac-dependent cell migration. Cell 118: 111-125.

Gerhold AR, Richter DJ, Yu AS, Hariharan IK. 2011. Identification and characterization of genes required for compensatory growth in Drosophila. Genetics 189: 1309 1326.

Ghavami S, Hashemi M, Ande SR, Yeganeh B, Xiao W, Eshraghi M, Bus CJ, Kadkhoda K, Wiechec E, Halayko AJ, et al. 2009. Apoptosis and cancer: Mutations within caspase genes. J Med Genet 46: 497-510.

Giardiello FM, Hamilton SR, Krush AJ, Piantadosi S, Hylind LM, Celano P, Booker SV, Robinson CR, Offerhaus GJ. 1993. Treatment of colonic and rectal adenomas with sulindac in familial adenomatous polyposis. $N$ Engl $J$ Med 328: 1313-1316.

Goessling W, North TE, Loewer S, Lord AM, Lee S, StoickCooper CL, Weidinger G, Puder M, Daley GQ, Moon RT, et al. 2009. Genetic interaction of PGE2 and Wnt signaling regulates developmental specification of stem cells and regeneration. Cell 136: 1136-1147.

Gowda PS, Zhou F, Chadwell LV, McEwen DG. 2012. p53 binding prevents phosphatase-mediated inactivation of diphosphorylated JUN N-terminal kinase. J Biol Chem 287: 17554-17567.

Greten FR, Eckmann L, Greten TF, Park JM, Li ZW, Egan LJ, Kagnoff MF, Karin M. 2004. IKK $\beta$ links inflammation and tumorigenesis in a mouse model of colitis-associated cancer. Cell 118: 285-296.

Grether ME, Abrams JM, Agapite J, White K, Steller H. 1995. The head involution defective gene of Drosophila melanogaster functions in programmed cell death. Genes Dev 9: $1694-1708$.

Grzeschik NA, Parsons LM, Allott ML, Harvey KF, Richardson HE. 2010. Lgl, aPKC, and Crumbs regulate the Salvador/Warts/Hippo pathway through two distinct mechanisms. Curr Biol 20: 573-581. 
Gurley KA, Rink JC, Sanchez Alvarado A. 2008. $\beta$-catenin defines head versus tail identity during planarian regeneration and homeostasis. Science 319: 323-327.

Hanahan D, Weinberg RA. 2000. The hallmarks of cancer Cell 100: $57-70$.

Hawkins CJ, Yoo SJ, Peterson EP, Wang SL, Vernooy SY, Hay BA. 2000. The Drosophila caspase DRONC cleaves following glutamate or aspartate and is regulated by DIAP1, HID, and GRIM. J Biol Chem 275: 27084-27093.

Haynie JL, Bryant PJ. 1977. The effects of X-rays on the proliferation dynamics of cells in the imaginal wing disc of Drosophila melanogaster. Roux's Arch Dev Biol 183: $85-100$.

He G, Karin M. 2011. NF-кB and STAT3-key players in liver inflammation and cancer. Cell Res 21: 159-168.

Herz HM, Chen Z, Scherr H, Lackey M, Bolduc C, Bergmann A. 2006. vps25 mosaics display non-autonomous cell survival and overgrowth, and autonomous apoptosis. Development 133: 1871-1880.

Huang Q, Li F, Liu X, Li W, Shi W, Liu FF, O'Sullivan B, He Z, Peng Y, Tan AC, et al. 2011. Caspase 3-mediated stimulation of tumor cell repopulation during cancer radiotherapy. Nat Med 17: 860-866.

Huh JR, Guo M, Hay BA. 2004. Compensatory proliferation induced by cell death in the Drosophila wing disc requires activity of the apical cell death caspase Dronc in a nonapoptotic role. Curr Biol 14: 1262-1266.

Hwang JS, Kobayashi C, Agata K, Ikeo K, Gojobori T. 2004. Detection of apoptosis during planarian regeneration by the expression of apoptosis-related genes and TUNEL assay. Gene 333: 15-25.

Igaki T, Kanda H, Yamamoto-Goto Y, Kanuka H, Kuranaga E, Aigaki T, Miura M. 2002. Eiger, a TNF superfamily ligand that triggers the Drosophila JNK pathway. EMBO J 21: 3009-3018.

Iolascon A, Borriello A, Giordani L, Cucciolla V, Moretti A, Monno F, Criniti V, Marzullo A, Criscuolo M, Ragione FD. 2003. Caspase 3 and 8 deficiency in human neuroblastoma. Cancer Genet Cytogenet 146: 41-47.

Jaklevic BR, Su TT. 2004. Relative contribution of DNA repair, cell cycle checkpoints, and cell death to survival after DNA damage in Drosophila larvae. Curr Biol 14: $23-32$.

Jing G, Yuan K, Liang Q, Sun Y, Mao X, McDonald JM, Chen Y. 2012. Reduced CaM/FLIP binding by a single point mutation in c-FLIP(L) modulates Fas-mediated apoptosis and decreases tumorigenesis. Lab Invest 92: 82-90.

Kanuka H, Kuranaga E, Takemoto K, Hiratou T, Okano H, Miura M. 2005. Drosophila caspase transduces Shaggy/ GSK-3 $\beta$ kinase activity in neural precursor development. EMBO J 24: 3793-3806.

Karin M, Lawrence T, Nizet V. 2006. Innate immunity gone awry: Linking microbial infections to chronic inflammation and cancer. Cell 124: 823-835.

Kerr JF, Wyllie AH, Currie AR. 1972. Apoptosis: A basic biological phenomenon with wide-ranging implications in tissue kinetics. Brit J Cancer 26: 239-257.

Kimura M, Matsuzawa A. 1994. Autoimmunity in mice bearing lprcg: A novel mutant gene. Int Rev Immunol 11: $193-210$.
Apoptosis-Induced Compensatory Proliferation

Kondo S, Senoo-Matsuda N, Hiromi Y, Miura M. 2006. DRONC coordinates cell death and compensatory proliferation. Mol Cell Biol 26: 7258-7268.

Krammer PH. 2000. CD95's deadly mission in the immune system. Nature 407: 789-795.

Kumar S. 2007. Caspase function in programmed cell death. Cell Death Differ 14: 32-43.

Kuranaga E, Kanuka H, Tonoki A, Takemoto K, Tomioka T, Kobayashi M, Hayashi S, Miura M. 2006. Drosophila IKKrelated kinase regulates nonapoptotic function of caspases via degradation of IAPs. Cell 126: 583-596.

Kurokawa H, Nishio K, Fukumoto H, Tomonari A, Suzuki T, Saijo N. 1999. Alteration of caspase-3 (CPP32/Yama/ apopain) in wild-type MCF-7, breast cancer cells. Oncol Rep 6: 33-37.

LaCasse EC, Mahoney DJ, Cheung HH, Plenchette S, Baird S, Korneluk RG. 2008. IAP-targeted therapies for cancer. Oncogene 27: 6252-6275.

Lengfeld T, Watanabe H, Simakov O, Lindgens D, Gee L, Law L, Schmidt HA, Ozbek S, Bode H, Holstein TW. 2009. Multiple Wnts are involved in Hydra organizer formation and regeneration. Dev Biol 330: 186-199.

Li Q, Van Antwerp D, Mercurio F, Lee KF, Verma IM. 1999. Severe liver degeneration in mice lacking the ІкВ kinase 2 gene. Science 284: 321-325.

Li F, Huang Q, Chen J, Peng Y, Roop DR, Bedford JS, Li CY. 2010. Apoptotic cells activate the "phoenix rising" pathway to promote wound healing and tissue regeneration. Sci Signal 3: ra13.

Ling C, Zheng Y, Yin F, Yu J, Huang J, Hong Y, Wu S, Pan D. 2010. The apical transmembrane protein Crumbs functions as a tumor suppressor that regulates Hippo signaling by binding to Expanded. Proc Natl Acad Sci 107: $10532-10537$

Maeda S, Kamata H, Luo JL, Leffert H, Karin M. 2005. IKK $\beta$ couples hepatocyte death to cytokine-driven compensatory proliferation that promotes chemical hepatocarcinogenesis. Cell 121: 977-990.

Mahrus S, Trinidad JC, Barkan DT, Sali A, Burlingame AL, Wells JA. 2008. Global sequencing of proteolytic cleavage sites in apoptosis by specific labeling of protein $\mathrm{N}$ termini. Cell 134: 866-876.

Meier P, Silke J, Leevers SJ, Evan GI. 2000. The Drosophila caspase DRONC is regulated by DIAP1. EMBO J 19: 598-611.

Milan M, Campuzano S, Garcia-Bellido A. 1997. Developmental parameters of cell death in the wing disc of Drosophila. Proc Natl Acad Sci 94: 5691-5696.

* Miura M. 2012. Apoptotic and non-apoptotic caspase functions in animal development. Cold Spring Harb Perspect Biol doi: 10.1101/cshperspect.a008664.

Moreno E, Yan M, Basler K. 2002. Evolution of TNF signaling mechanisms: JNK-dependent apoptosis triggered by Eiger, the Drosophila homolog of the TNF superfamily. Curr Biol 12: 1263-1268.

Nagata S. 1999. Fas ligand-induced apoptosis. Annu Rev Genet 33: 29-55.

Newsome TP, Asling B, Dickson BJ. 2000. Analysis of Drosophila photoreceptor axon guidance in eye-specific mosaics. Development 127: 851-860. 
H.D. Ryoo and A. Bergmann

North TE, Goessling W, Walkley CR, Lengerke C, Kopani KR, Lord AM, Weber GJ, Bowman TV, Jang IH, Grosser T, et al. 2007. Prostaglandin E2 regulates vertebrate haematopoietic stem cell homeostasis. Nature 447: 1007-1011.

Oshima K, Takeda M, Kuranaga E, Ueda R, Aigaki T, Miura M, Hayashi S. 2006. IKK epsilon regulates F actin assembly and interacts with Drosophila IAP1 in cellular morphogenesis. Curr Biol 16: 1531-1537.

Ouyang Y, Petritsch C, Wen H, Jan L, Jan YN, Lu B. 2011. Dronc caspase exerts a non-apoptotic function to restrain phospho-Numb-induced ectopic neuroblast formation in Drosophila. Development 138: 2185-2196.

Owen-Schaub LB, Meterissian S, Ford RJ. 1993. Fas/APO-1 expression and function on malignant cells of hematologic and nonhematologic origin. J Immunother Emphasis Tumor Immunol 14: 234-241.

Pearson BJ, Sanchez Alvarado A. 2010. A planarian p53 homolog regulates proliferation and self-renewal in adult stem cell lineages. Development 137: 213-221.

Pellettieri J, Sanchez Alvarado A. 2007. Cell turnover and adult tissue homeostasis: From humans to planarians. Annu Rev Genet 41: 83-105.

Perez-Garijo A, Martin FA, Morata G. 2004. Caspase inhibition during apoptosis causes abnormal signalling and developmental aberrations in Drosophila. Development 131: $5591-5598$

Perez-Garijo A, Martin FA, Struhl G, Morata G. 2005. Dpp signaling and the induction of neoplastic tumors by caspase-inhibited apoptotic cells in Drosophila. Proc Natl Acad Sci 102: 17664-17669.

Perez-Garijo A, Shlevkov E, Morata G. 2009. The role of Dpp and $\mathrm{Wg}$ in compensatory proliferation and in the formation of hyperplastic overgrowths caused by apoptotic cells in the Drosophila wing disc. Development 136: 11691177.

Peter ME, Budd RC, Desbarats J, Hedrick SM, Hueber AO, Newell MK, Owen LB, Pope RM, Tschopp J, Wajant H, et al. 2007. The CD95 receptor: Apoptosis revisited. Cell 129: $447-450$.

Petersen CP, Reddien PW. 2008. Smed- $\beta$ catenin-1 is required for anteroposterior blastema polarity in planarian regeneration. Science 319: 327-330.

Petersen CP, Reddien PW. 2009. A wound-induced Wnt expression program controls planarian regeneration polarity. Proc Natl Acad Sci 106: 17061-17066.

Reddien PW, Bermange AL, Kicza AM, Sanchez Alvarado A. 2007. BMP signaling regulates the dorsal planarian midline and is needed for asymmetric regeneration. Development 134: 4043-4051.

Rink JC, Gurley KA, Elliott SA, Sanchez Alvarado A. 2009. Planarian Hh signaling regulates regeneration polarity and links Hh pathway evolution to cilia. Science 326: 1406-1410.

Ryoo HD, Gorenc T, Steller H. 2004. Apoptotic cells can induce compensatory cell proliferation through the JNK and the Wingless signaling pathways. Dev Cell 7: 491-501.

Safa AR, Pollok KE. 2011. Targeting the anti-apoptotic protein c-FLIP for cancer therapy. Cancers 3: 1639-1671.

Sakurai T, He G, Matsuzawa A, Yu GY, Maeda S, Hardiman G, Karin M. 2008. Hepatocyte necrosis induced by oxi- dative stress and IL- $1 \alpha$ release mediate carcinogen-induced compensatory proliferation and liver tumorigenesis. Cancer Cell 14: 156-165.

Sandu C, Ryoo HD, Steller H. 2010. Drosophila IAP antagonists form multimeric complexes to promote cell death. J Cell Biol 190: 1039-1052.

Shapiro PJ, Hsu HH, Jung H, Robbins ES, Ryoo HD. 2008. Regulation of the Drosophila apoptosome through feedback inhibition. Nat Cell Biol 10: 1440-1446.

Shlevkov E, Morata G. 2012. A dp53/JNK-dependant feedback amplification loop is essential for the apoptotic response to stress in Drosophila. Cell Death Differ 19: 451-460.

Silva E, Tsatskis Y, Gardano L, Tapon N, McNeill H. 2006. The tumor-suppressor gene fat controls tissue growth upstream of expanded in the hippo signaling pathway. Curr Biol 16: 2081-2089.

Smith-Bolton RK, Worley MI, Kanda H, Hariharan IK. 2009. Regenerative growth in Drosophila imaginal discs is regulated by Wingless and Myc. Dev Cell 16: 797-809.

Stoick-Cooper CL, Weidinger G, Riehle KJ, Hubbert C, Major MB, Fausto N, Moon RT. 2007. Distinct Wnt signaling pathways have opposing roles in appendage regeneration. Development 134: 479-489.

Stowers RS, Schwarz TL. 1999. A genetic method for generating Drosophila eyes composed exclusively of mitotic clones of a single genotype. Genetics 152: 1631-1639.

Suissa Y, Ziv O, Dinur T, Arama E, Gerlitz O. 2011. The NAB-Brk signal bifurcates at JNK to independently induce apoptosis and compensatory proliferation. J Biol Chem 286: 15556-15564.

Sun G, Irvine KD. 2011. Regulation of Hippo signaling by Jun kinase signaling during compensatory cell proliferation and regeneration, and in neoplastic tumors. Dev Biol 350: 139-151.

Tamm I, Kornblau SM, Segall H, Krajewski S, Welsh K, Kitada S, Scudiero DA, Tudor G, Qui YH, Monks A, et al. 2000. Expression and prognostic significance of IAP-family genes in human cancers and myeloid leukemias. Clin Cancer Res 6: 1796-1803.

Thornberry NA, Lazebnik Y. 1998. Caspases: Enemies within. Science 281: 1312-1316.

Trembley A. 1744. Meoires pour sevir al'hisoire d'un genre de polyps d'eao douce. JuH Verbeek, Leiden.

Tseng AS, Adams DS, Qiu D, Koustubhan P, Levin M. 2007. Apoptosis is required during early stages of tail regeneration in Xenopus laevis. Dev Biol 301: 62-69.

Vlaskalin T, Wong CJ, Tsilfidis C. 2004. Growth and apoptosis during larval forelimb development and adult forelimb regeneration in the newt (Notophthalmus viridescens). Dev Genes Evol 214: 423-431.

Voas MG, Rebay I. 2004. Signal integration during development: Insights from the Drosophila eye. Dev Dyn 229: $162-175$.

Vousden KH. 2000. p53: Death star. Cell 103: 691-694.

Warner SJ, Yashiro H, Longmore GD. 2010. The Cdc42/ Par6/aPKC polarity complex regulates apoptosis-induced compensatory proliferation in epithelia. Curr Biol 20: 677-686. 
Wells BS, Johnston LA. 2012. Maintenance of imaginal disc plasticity and regenerative potential in Drosophila by 53 . Dev Biol 361: 263-276.

Wells BS, Yoshida E, Johnston LA. 2006. Compensatory proliferation in Drosophila imaginal discs requires Dronc-dependent p53 activity. Curr Biol 16: 1606-1615.

White K, Tahaoglu E, Steller H. 1996. Cell killing by the Drosophila gene reaper. Science 271: 805-807.

Willecke M, Hamaratoglu F, Kango-Singh M, Udan R, Chen CL, Tao C, Zhang X, Halder G. 2006. The fat cadherin acts through the hippo tumor-suppressor pathway to regulate tissue size. Curr Biol 16: 2090-2100.

Xu D, Li Y, Arcaro M, Lackey M, Bergmann A. 2005. The CARD-carrying caspase Dronc is essential for most, but not all, developmental cell death in Drosophila. Development 132: 2125-2134.

Xu D, Wang Y, Willecke R, Chen Z, Ding T, Bergmann A. 2006. The effector caspases drICE and dcp-1 have par- tially overlapping functions in the apoptotic pathway in Drosophila. Cell Death Differ 13: 1697-1706.

Xue D, Horvitz HR. 1995. Inhibition of the Caenorhabditis elegans cell-death protease CED-3 by a CED-3 cleavage site in baculovirus p35 protein. Nature 377: 248-251.

Yang JK. 2008. FLIP as an anti-cancer therapeutic target. Yonsei Med J 49: 19-27.

Yang J, Splittgerber R, Yull FE, Kantrow S, Ayers GD, Karin M, Richmond A. 2010. Conditional ablation of Ikkb inhibits melanoma tumor development in mice. J Clin Invest 120: $2563-2574$.

Yu X, Wang L, Acehan D, Wang X, Akey CW. 2006. Threedimensional structure of a double apoptosome formed by the Drosophila Apaf-1 related killer. J Mol Biol 355: 577-589.

Yuan J, Shaham S, Ledoux S, Ellis HM, Horvitz HR. 1993. The $C$. elegans cell death gene ced- 3 encodes a protein similar to mammalian interleukin-1 $\beta$-converting enzyme. Cell 75: 641-652. 


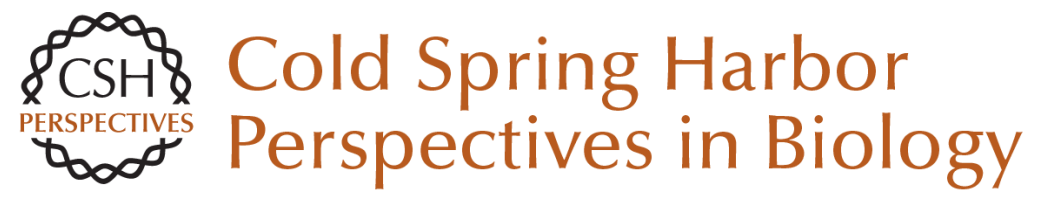

\section{The Role of Apoptosis-Induced Proliferation for Regeneration and Cancer}

Hyung Don Ryoo and Andreas Bergmann

Cold Spring Harb Perspect Biol 2012; doi: 10.1101/cshperspect.a008797

Subject Collection

For additional articles in this collection, see http://cshperspectives.cshlp.org/cgi/collection/

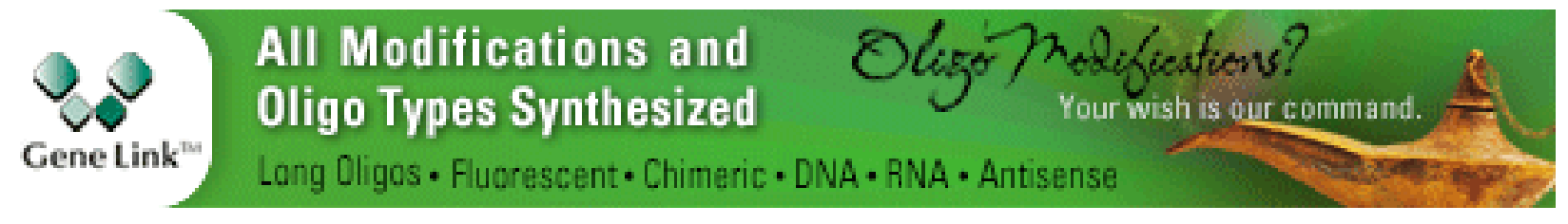

Copyright @ 2012 Cold Spring Harbor Laboratory Press; all rights reserved 